\title{
Mockingbirds at Oak Lake, Manitoba
}

\author{
by David Hatch, Oak Loke
}

In Frank Brazier's article on the "Status of the Mockingbird. in the Northern Great Plains" Blue Jay, 22: 63-75), the Manitoba records cited include a Mockingbird seen December 26 , 1962, at Oak Lake. This was a bird that spent the first part of the winter of 1962-1963 at Oak Lake. I first saw it on November 17, 1962, in the house yard on the farm of my parents, Mr. and Mrs. Lloyd M. Hatch. This was the first one I had ever seen and was the first Oak Lake record. Besides having all the typical Mockingbird characteristics, it occasionally cocked its tail as the Catbirds sometimes do. As it frequently flew only three feet off the ground from one tree to another, I set up my Japanese mist net next to a lilac bush and after three hours I finally caught it and banded it. Despite the late date, the Mockingbird was in excellent condition.

This Mockingbird was seen daily at the Hatch residence until November 23, 1962, when it flew the half mile across open prairie to the farm yard of Mr. Herman Battersby. For the next few days, it moved back and forth between the two farms. After November 27, it was rarely seen at the Hatch farm and was never seen there after December 31, 1962. It found more shelter at the Battersby farm grove and as the winter grew more and more severe it never left the shelterbelt.

On the Hatch farm, the Mockingbird spent the nights in a pile of straw bales. It ate the berries off all the honeysuckle bushes and also ate white bread crumbs and raisins that we put out for it. At Mr. Battersby's, it occasionally ate dried apples, but most of its food was mountain ash berries. It jealously guarded the mountain ash tree and was so aggressive in protecting it that it was able to keep an entire flock of Bohemian Waxwings out of the tree.

I never heard the Mockingbird make any noise, but one day, December 14, Mr. Battersby heard it call a few times. He described the sound as a sort of "chirp like a thrush makes."

While at Mr. Battersby's, the Mockingbird slept each night on a broken branch just a few inches above the snow level at the south end of a row of lilacs. During the daytime, it spent a great deal of its time sitting on this branch. It was last seen alive on January 14, 1963. When Mr. Battersby noticed that it was not around the buildings on January 15 it was not hard for him to find it; it was dead on the snow just under the branch on which it spent so much time. A severe cold spell coupled with strong winds had probably been the cause of its death.

The Mockingbird was seen daily from November 17, 1962, to January 14, 1963. This is a very interesting record, not only because it was the first Oak Lake record of the Mockingbird, but because the bird attempted to remain in the area for the winter.

Oak Lake was not again visited by a Mockingbird until September 6, 1964. On this date a single Mockingbird was observed by both Mr. Battersby and myself. It appeared to be in the midst of a heavy moult; the feathers over all its body were worn and quill feathers could be distinguished at close range through $7 \times 50$ binoculars. It looked as if it was regrowing its entire tail and was very shabby in appearance.

The following day, September 7, 1964, Mr. Battersby had the good fortune to see six Mockingbirds at one time in the same place as the mocker was seen the previous day. One of the six was probably the one seen September 6 as its feathers were in rough condition. The other five Mockingbirds were sleek and well-feathered. They were also grey-brown on the back instead of pale grey as in the moulting bird. This is the largest group of Mockingbirds ever seen in Manitoba; it suggests that they may have nested in the area. Later, on September 20, I saw a group of three. These birds were two miles southeast of where the six were seen on September 7 and were in some willows along a country road. They were only seen one day and were the last ones noted in the Oak Lake area in 1964. 